\title{
Clinical Features and Pain Characteristics of Cluster Headache
}

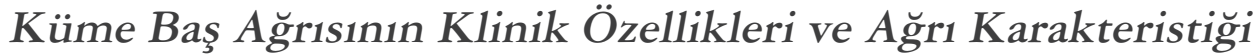

\author{
University of Health Sciences Turkey, Istanbul Bakirkoy Prof. Dr. Mazhar Osman Mental and Neurological Diseases Training and Research \\ Hospital, Clinic of Neurology, Istanbul, Turkey
}

\begin{abstract}
Objective: Trigeminal autonomic headaches are the primary headache group that occurs with autonomic stimulation of the cranial nerves. The most common type of this group is cluster headache $(\mathrm{CH})$. This study aimed to report the clinical features and pain characteristics of patients with $\mathrm{CH}$.

Materials and Methods: Patients of the outpatient headache center between 2010 and 2020 were retrospectively analyzed. Inclusion criteria were diagnosis of $\mathrm{CH}$ and a minimum of 1 -year follow-up. Records were reviewed using the International Headache Classification-3 $\beta$. The sociodemographic characteristics of patients, types of pain, pain characteristics, and treatments that were used were documented. Clinical features were compared with sociodemographic characteristics and factors that could affect the pain features.

Results: The mean age of 32 patients (25 male and 7 female) was 41.8 (23-68) years, and the mean age at disease onset was 31.7 (15-65) years. Lacrimation followed by conjunctival injection were the most common autonomic findings. According to gender, no statistical significance was found between pain character $(\mathrm{p}=0.166)$, painful side $(\mathrm{p}=0.572)$, month of onset $(\mathrm{p}=0.562)$, accompanying autonomic findings $(\mathrm{p}=0.495)$, pain duration $(\mathrm{p}=0.650)$, pain occurrence time during the day ( $\mathrm{p}=0.394$ ), and localization (Retroorbital/orbital, $\mathrm{p}=0.602$; temporal, $\mathrm{p}=0.650$; and forehead $\mathrm{p}=0.394)$. Nine patients had migraine-like features (MLF). The pain duration of patients with MLF was found to be $1.14 \pm 0.6$ months and this period was longer than the results of other patients. No statistically significant difference was found between pain characteristics.
\end{abstract}

Conclusion: The delay in diagnosis due to MLF that may accompany shows the importance of increasing awareness in the definition of $\mathrm{CH}$.

Keywords: Primary headache, cluster headache, trigeminal autonomic headache, migraine-like features

Öz

Amaç: Trigeminal otonomik baş ağrıları, kafa çiftlerinin otonom uyarılmasıyla ortaya çıkan primer baş ağrısı grubudur. En sık görülen tipi küme baş ağrısıdır (KB). Bu çalışmada KB'nin klinik bulgularının ve ağrı karakterinin incelenmesi amaçlanmıştır.

Gereç ve Yöntem: Eğitim araştırma hastanesi baş ağrısı polikliniklerine 2010-2020 arasında başvurmuş, Uluslararası Baş Ağrısı Sınıflaması-3 $\beta$ versiyonuna göre, KB tanısı ile en az 1 yıldır takip edilen hastalar çalışmaya dahil edildi. Hastaların sosyodemografik özellikleri, ağrı özellikleri, kullanılan tedaviler retrospektif olarak incelendi. A $\breve{g r}$ k klinikleri ile sosyodemografik özellikler ve ağr1 özelliklerine etki edebilecek faktörler karşılaştırıldı.

Bulgular: Çalışmaya 32 hasta alındı. Yirmi beş erkek, yedi kadın hastanın yaş ortalaması 41,8 (23-68), hastalığın başlangıç yaş ortalaması 31,7 (15-65) idi. Gözde yaşarma ve ardından gözde kızarma en sık görülen otonom bulguları oluşturmaktaydı. Ağrı özellikleri cinsiyetlere göre karşılaştırıldığında ağrı karakteri, ağrılı taraf, başlangıç ayı, eşlik eden otonomik bulgular, ağrı süresi ve ağrının gün içindeki oluşum saati arasında istatistiksel anlamlılık tespit edilmedi (sırasıyla; $\mathrm{p}=0,166, \mathrm{p}=0,572, \mathrm{p}=0,562$, göz $\mathrm{p}=0,495$, şakak $\mathrm{p}=0,364$, alın $\mathrm{p}=0,602, \mathrm{p}=0,650, \mathrm{p}=0,394$ ). Dokuz hastada migren benzeri özellikler (MLF) bulunmaktayd1. MLF eşik eden hastaların ağrı süresi $1,14 \pm 0,6$ ay olarak bulundu ve bu sürenin diğer hastaların sonuçlarına göre daha uzun olduğu izlendi. Ancak iki grup kıyaslandığında ağrı süresi dahil ağrı özellikleri, başlangıç yaşı, aile öyküsü, arasında istatistiksel anlamlı fark gözlenmedi.

Sonuç: Bu çalışmada KB'nin klinik bulguları gözden geçirildi. Özellikle eşlik edebilen migren benzeri bulgular nedeniyle tanı almada gecikme yaşanması, KB'nin tanımlanmasında farkındalı̆̆ın artmasının önemini göstermektedir.

Anahtar Kelimeler: Primer baş ağrısı, küme baş ağrısı, trigeminal otonomik baş ă̆rıları, migren benzeri özellikler

Address for Correspondence/Yazıșma Adresi: Fulya Eren MD, University of Health Sciences Turkey, Istanbul Bakirkoy Prof. Dr. Mazhar Osman Mental and Neurological Diseases Training and Research Hospital, Clinic of Neurology, Istanbul, Turkey Phone: +90 5322276160 E-mail: fulyasengul@yahoo.com ORCID: orcid.org/0000-0001-9787-7551 Received/Geliș Tarihi: 23.12.2020 Accepted/Kabul Tarihi: 12.05 .2021

${ }^{\circ}$ Copyright 2021 by Turkish Neurological Society

Turkish Journal of Neurology published by Galenos Publishing House. 


\section{Introduction}

Headache, which is the most common complaint in neurologic practice, occurs due to primary and secondary causes. Trigeminal autonomic headaches are the primary headache group that occurs with autonomic stimulation of the cranial nerves. The most common type of this group is cluster headache $(\mathrm{CH}) . \mathrm{CH}$ is less common compared to other primary headaches. Its prevalence has been reported as $0.12 \%$ for life, varying from country to country, and is more common in men than in women. The male to female ratio was suggested to range between 2.5:1 and 3.5:1 $(1,2)$. Although it is seen at all ages, the most common is between 20 and 40 years (3). Headache attacks are unilateral and severe that last for 15-180 s and mostly localized at the orbital area in the form of periods (clusters). The pain is accompanied by at least one autonomic finding (such as conjunctival injection and/or lacrimation, nasal congestion and/or rhinorrhea, eyelid edema, and forehead sweating) or agitation (4).

$\mathrm{CH}$ diagnosis is reported according to the International Headache Classification 3-beta (ICHD-3 $\beta$ ) version (Table 1). Accordingly, $\mathrm{CH}$ was defined as episodic, chronic, and probable, and $85-90 \%$ of patients have episodic presentation. These patients have headaches that last for days to weeks, occur in attacks once or more a day, and a remission period for months to years. Pain is mostly observed in spring and autumn and is noted with a circadian rhythm. Chronic $\mathrm{CH}$ diagnoses are found in $10-15 \%$ of patients, who may have pain that lasts for 1 year or remission periods of $<1$ month. Patients with trigeminal autonomic headache findings but not meeting other criteria are also defined as probable $\mathrm{CH}$ (5).

Three important structures are thought to be effective in the pathophysiology of $\mathrm{CH}$, namely, the trigeminovascular system, parasympathetic nerve fibers, and hypothalamus. However, the model of action of these structures and their relations with each other are still uncertain (6).

Trigeminal autonomic reflex occurs when the trigeminal nerve activates the parasympathetic system via the superior salivatory nucleus. Thus, vasoactive neuropeptides are released, and autonomic findings occur $(7,8)$. Its relationship to the hypothalamus is suspected as the pain occurs in a circadian rhythm. The functional neuroimaging studies detected activation in the ipsilateral inferior hypothalamus gray matter during $\mathrm{CH}$ (9).

Autosomal dominant inheritance was found in $5 \%$ of patients with $\mathrm{CH}$. Studies suggest that the pituitary adenylate cyclaseactivating polypeptide (PACAP) receptor gene, $A D C Y A P 1 R 1$, may be associated with $\mathrm{CH}$. Increased plasma concentration of $P A C A P$ during the headache attack seems to support this finding. However, further investigation is needed for a solid conclusion (10).

This study aimed to report the clinical features and pain characteristics of patients with $\mathrm{CH}$. Therefore, sociodemographic characteristics, pain clinics, treatments, and factors affecting the pain characteristics of patients who were followed up with a diagnosis of $\mathrm{CH}$ were evaluated.

\section{Materials and Methods}

The outpatient visits of patients to the Headache Center of University of Health Sciences Turkey, Istanbul Bakirkoy Prof. Dr. Mazhar Osman Mental and Neurological Diseases Training and
Research Hospital between 2010 and 2020 were retrospectively analyzed. Inclusion criteria were $\mathrm{CH}$ diagnosis and a minimum of 1 -year follow-up. Records were reviewed using the ICHD-3 $\beta$ to identify patients with $\mathrm{CH}$. According to this classification, patients with episodic clusters (ICD code 3.1.1) and chronic $\mathrm{CH}$ (ICD code 3.1.2) were included in the study. Patients with other types of headaches accompanying $\mathrm{CH}$ were not excluded. Patients with migraine and tension and those with missing records regarding sociodemographic characteristics, pain type, and pain characteristics were excluded from the study. The sociodemographic characteristics of patients, types of pain, pain characteristics, and treatments used were documented. Clinical features were compared with sociodemographic characteristics and factors that could affect the pain features.

All procedures performed in studies involving human participants followed the ethical standards of the institutional and/or national research committee and with the 1964 Helsinki Declaration and its later amendments or comparable ethical standards.

\section{Statistical Analysis}

Statistical analyzes were performed using the Statistical Package for the Social Sciences (version 26, IBM, New York, USA) software. Descriptive statistical methods (mean and standard deviation in normally distributed data) was used when reporting the data. The relationship between gender and sociodemographic characteristics and family history and age-onset were determined using an independent t-test. Sex, family history, pain characteristics, migraine-like features (MLF), and side shift were evaluated using chi-square and Fisher's Exact tests. In this study, a p-value below 0.05 was considered statistically significant.

\section{Ethical Approval}

Before the study, approval was obtained from University of Health Sciences Turkey, Istanbul Bakirkoy Dr. Sadi Konuk Training and Research Hospital in 01.02.2021 with the number 2021/03.

\section{Results}

\section{Sociodemographic Results}

A total of 32 patients with adequate available data on the database were included in the study. The mean age of 25 male and 7 female patients was 41.8 (23-68) years, and the mean age on disease onset was $31.7(15-65)$ years. The age of onset was $37.6 \pm 15$ in female patients and $29.9 \pm 14.1$ in males. No statistically significant difference was found in the age of onset between the two genders $(\mathrm{p}=0.225)$ (Table 2).

Smoking was recorded in 14 patients, history of head trauma in 4 , and history of other accompanying diseases in 14 patients (Table 3). Familial history of headaches was found in 11 patients, wherein 9 were first-degree and 2 were second-degree relatives. However, obtaining the type of headache was impossible. The mean age of disease onset was found to be $25.82 \pm 11.7$ years in patients with a family history of headache, whereas $35.1 \pm 15.1$ years in those without a family history. No statistically significant correlation was observed $(\mathrm{p}=0.089)$ (Table 2$)$. 


\section{Clinical Results}

According to the ICHD-3 $\beta$ classification, 29 patients were diagnosed with episodic $\mathrm{CH}$ and 3 with chronic $\mathrm{CH}$. In addition to $\mathrm{CH}$ diagnosis, 3 patients were diagnosed with migraine headache without aura.

The pain characteristics of patients with unilateral, severe, autonomic symptoms, and pain with certain periods showed some differences. Reported pain characters were sharp in 22, pulsatile in 7 , and pressure in 3 patients. The lateralization of headache in 26 patients was documented as unilateral, bilateral in 3 , and variable in 3 patients. Side shift of the pain between cycles or headaches was reported in 5 patients, whereas, the most common area of pain in patients was the retroorbital/orbital and followed by the temporal and forehead (Table 4). Different autonomic findings were observed in all patients in isolation or groups. Lacrimation $(\mathrm{n}=27)$ followed by conjunctival injection $(\mathrm{n}=22)$ were the most common autonomic findings (Table 5).

The periods of $\mathrm{CH}$ onset varied throughout the year. Pain attacks were experienced by 19 patients in the spring or autumn months, 6 in winter, 2 in the summer, and 5 in varying months. Attacks of 24 patients occurred at night or in the second half of the day, whereas 4 patients experienced it in the morning or the first

\section{Table 1. Diagnostic criteria of $\mathrm{CH}$ in ICHD-3 $\beta$}

A. At least five attacks that fulfill criteria B-D

B. Severe or very severe unilateral orbital, supraorbital, and/or temporal pain that last for $15-180 \mathrm{~min}$ (when untreated)

C. Either or both of the following:

1. At least one of the following symptoms or signs, ipsilateral

to the headache:

a) Conjunctival injection and/or lacrimation

b) Nasal congestion and/or rhinorrhea

c) Eyelid edema

d) Forehead and facial sweating

e) Forehead and facial flushing

f) Sensation of fullness in the ear

g) Miosis and/or ptosis

2. A sense of restlessness or agitation

D. Attacks have a frequency between one every other day and eight per day for more than half of the time when the disorder is active

E. Not better accounted for by another ICHD-3 diagnosis ICHD-3 $\beta$ : International Headache Classification 3-beta, $\mathrm{CH}$ : Cluster headache

\section{Table 2. Gender and age distribution of patients}

\begin{tabular}{lll|} 
Number of patients & 32 & \\
Female & 7 & \\
Male & 25 & \\
Mean age, years & $41.8(23-68)$ & \\
Mean age of onset, years & $31.7(15-65)$ & \\
Female & $37.6 \pm 15$ & $\mathrm{p}=0.225^{*}$ \\
Male & $29.9 \pm 14.1$ & \\
With family history & $25.8 \pm 11.7$ & $\mathrm{p}=0.089^{*}$ \\
Without family history & $35.1 \pm 15.1$ & \\
*Student t-test & & \\
\hline
\end{tabular}

half of the day. Times of onset of attacks in 4 patients were varying (Table 6). The painful periods of the patients lasted an average of 1.14 months $(0.5-3)$.

The comparison of the pain characteristics according to gender found no statistical significance between pain character $(p=0.166)$, painful side $(\mathrm{p}=0.572)$, month of onset $(\mathrm{p}=0.562)$, accompanying

\begin{tabular}{|lc|}
\hline $\begin{array}{l}\text { Table 3. Medical conditions in patients with cluster } \\
\text { headache }\end{array}$ & Patient (n) \\
Medical condition & 4 \\
Motion (car) sickness & 4 \\
Hypertension & 3 \\
Diabetes mellitus & 2 \\
Allergy & 1 \\
Cardiac by-pass surgery & 1 \\
Gastrointestinal bleeding & 1 \\
Cervix carcinoma & \\
\hline
\end{tabular}

Table 4. Laterality, pain character, side shifting, and location distribution

$\begin{array}{ll}\text { Cluster headache characteristics } & \text { Patient (n) } \\ \text { Laterality } & 10 \\ \text { Right } & 16 \\ \text { Left } & 3 \\ \text { Bilateral } & 3 \\ \text { Variable } & \\ \text { Pain character } & 22 \\ \text { Sharp } & 7 \\ \text { Pulsatile } & 3 \\ \text { Pressure } & 5 \\ \text { Side shift in between cycles or headaches } & \\ \text { Location } & 26 \\ \text { Retroorbital/orbital } & 19 \\ \text { Temporal } & 18 \\ \text { Temporal and orbital } & 2 \\ \text { Forehead and orbital } & \end{array}$

\section{Table 5. Associated symptoms in cluster headache}

\begin{tabular}{lll|} 
Symptoms & Patient (n) & Patient (\%) \\
Lacrimation & 27 & 84.37 \\
Conjunctival injection & 22 & 68.7 \\
Eyelid edema & 8 & 25 \\
Nasal congestion & 5 & 15.6 \\
Rhinorrhea & 4 & 12.5 \\
Nausea & 4 & 12.5 \\
Photophobia & 4 & 12.5 \\
Phonophobia & 3 & 9.37 \\
\hline
\end{tabular}


autonomic findings $(\mathrm{p}=0.495)$, pain duration $(\mathrm{p}=0.650)$, pain occurrence time during the day $(\mathrm{p}=0.394)$, and localization (Retroorbital/orbital $\mathrm{p}=0.602$, temporal $\mathrm{p}=0.650$, and forehead $\mathrm{p}=0.394)$.

Some patients were noted with MLF along with autonomic findings. Nausea and phono and photophobia findings in 9 patients accompany the pain. The pain duration of patients with MLF was found to be $1.14 \pm 0.6$ months and this period was observed to be longer than the results of other patients. However, no statistically significant difference was found between pain characteristics, including pain duration, age of onset, and family history between the two groups (Table 7).

Prophylactic treatment during the attack period was given to 26 patients and none 6 patients. The most commonly used prophylactic agent was verapamil, whereas valproic acid was used in the second place. All patients were also using short-term treatments during the attack periods. The most commonly used attack treatment options were rizatriptan, sumatriptan, and zolmitriptan. All patients applied to the emergency department and received oxygen inhalation at least once.

\section{Discussion}

$\mathrm{CHs}$ are presented with unique clinical features, and several demographic and pain characteristics were associated with this condition. This study observed male gender dominancy, a mean presentation age of 41.8 years, frequent eye-related autonomic findings, frequent spring and autumn onset, earlier onset in patients with family history, and circadian rhythm with nighttime onset. Despite its specific clinical features, $\mathrm{CH}$ can easily be confused with migraine, which may cause late diagnosis due to this resemblance.

$\mathrm{CH}$ is observed more frequently in men. Studies conducted in Asia revealed that the male to female ratio is slightly higher than in western countries, reported as 3.8-7:1 and 1.3-3.5:1 in western studies, respectively (11). This difference is thought to be related to cultural and ethnic values. Our study revealed a male to female ratio of 3.57:1. Although this was a small patient sample, a male to female ratio in between may be associated with our geographical location and cultural diversity between the European and Asian countries.

Approximately $42 \%$ of patients with $\mathrm{CH}$ were diagnosed later than 5 years after the symptoms started and $22 \%$ later than 10 years. The average age of onset of the disease was reported to be between the ages of 20-40 years. This type of headache is observed very rarely in adolescence and childhood $(3,11,12)$. Onset after the

Table 6. Variation of periods throughout the year or day

\begin{tabular}{lll|} 
Attack period during the year & Patient (n) & Patient $(\%)$ \\
Spring/autumn & 19 & 59.3 \\
Winter & 6 & 18.75 \\
Summer & 2 & 6.25 \\
Variable & 5 & 15.6 \\
Attack period during the day & & \\
Nighttime & 24 & 75 \\
Daytime & 4 & 12.5 \\
Variable & 4 & 12.5 \\
\hline
\end{tabular}

age of 50 years is defined as "late-onset" and before the age of 20 years as "early-onset." Although late-onset is thought to be very rare, recent studies show that it is more frequent than expected (12). In our study, the age of disease onset was under 50 years in $83.3 \%$ of patients, which is consistent with the literature. Earlyonset was presented by $13.3 \%$ of patients, the youngest of which at age of 15 years.

Table 7. Comparison of pain characteristics according to accompanying migraine-like features

$\begin{array}{lll}\text { without } & \text { with } & \text { p } \\ \text { MLF } & \text { MLF } & \end{array}$

Pain character

(n)

Sharp

Pressure

$16 \quad 6$

Pulsatile

1

Pain side

(n)

$\begin{array}{llll}\text { Unilateral } & 20 & 6 & \mathrm{p}=0.276^{*} \\ \text { Bilateral } & 1 & 2 & \\ \text { Variable } & 2 & 1 & \end{array}$

Location

(n)

$\begin{array}{llll}\text { Retroorbital/orbital } & 19 & 9 & \mathrm{p}=0.303^{*} \\ \text { Temporal } & 16 & 6 & \mathrm{p}=0.595^{*} \\ \text { Forehead } & 1 & 1 & \mathrm{p}=0.490^{*}\end{array}$

Side shift

(n)

Yes

No

3

20

$\mathrm{p}=0.604^{* *}$

Smoking

(n)

Yes

No

$\begin{array}{ll}10 & 4 \\ 13 & 5\end{array}$

Attack period/year

(n)

Spring/autumn

Winter

Summer

Variable

$\begin{array}{lll}12 & 7 & \mathrm{p}=0.768^{*} \\ 5 & 1 & \\ 2 & 0 & \\ 4 & 1 & \end{array}$

Attack period/day

(n)

Nighttime

Daytime

Variable

16

6

$\mathrm{p}=0.224^{*}$

Family history

(n)

\begin{tabular}{llll|}
$\begin{array}{l}\text { Positive } \\
\text { Negative }\end{array}$ & 8 & 3 & $\mathrm{p}=0.938^{*}$ \\
$\begin{array}{l}\text { Pain duration } \\
\text { (month } \pm \text { SD) }\end{array}$ & $0.9 \pm 0.2$ & $1.14 \pm 0.6$ & $\mathrm{p}=0.332+$ \\
$\begin{array}{l}\text { Age of onset } \\
\text { (mean } \pm \text { SD) }\end{array}$ & $32.5 \pm 14.8$ & $29.9 \pm 14.2$ & $\mathrm{p}=0.661+$ \\
$\begin{array}{l}\text { *Chi-square, **Fisher's Exact test, +Independent } \\
\text { features, SD: Standard deviation }\end{array}$ & & 6 & \\
\hline
\end{tabular}


Studies have shown that the age of onset is earlier in women than in men, but after the age of 50 years, a second peak is seen in female patients. Therefore, women are considered to be the majority in the late-onset patient group (13). This study revealed a trend toward older age in female patients, which has no statistically significant difference between genders. This may be associated with the small sample size of female patients. The female to male ratio was 4:1 in the late-onset patient group, which is consistent with the literature.

Studies reported that clinical characteristics do not show gender differences. A study conducted in Korea revealed that forehead and facial sweating was less in women than men, but all other pain characteristics were similar in both genders (14). Our study found no statistical association between gender pain characteristics.

In our study, $44 \%$ of patients were smokers. In the literature, it ranges between $51-92.5 \%(15,16)$. It was noteworthy that our smoking frequency was below the literature. According to a review published on $\mathrm{CH}$, the frequency of head trauma varied between $5-39 \%$ (17). In our study, a history of head trauma was reported in $12.5 \%$ of patients. A population-based study revealed much different comorbidity in patients with $\mathrm{CH}$, which corresponds to our study (18).

A review study published in 2020 reported that $8.2 \%$ of patients diagnosed with $\mathrm{CH}$ had a family history. Family history was observed to be higher in female patients than in men. However, this was associated with a male-dominant distribution (19). A study conducted in the United States of America reported that $52 \%$ of patients had a family history of migraine (15). In our study, $34.3 \%$ of patients had a history of headaches in their first and second-degree relatives. However, the limitation of this data is that the type of headache in the family is unknown.

Children of patients with $\mathrm{CH}$ had earlier onset, which may be related to genetic background (20). Taga et al. (21) reported that $\mathrm{CH}$ starts at an earlier age in women with a family history. Our study results support the literature, which shows that patients with a family history present symptoms approximately 10 years earlier than those without a family history. However, this trend was not found to be significant.

Patients with migraine are known to present with autonomic findings, whereas some present with MLF. The most common autonomic finding in migraine is lacrimation, which is also the most common in $\mathrm{CH}$. This renders differential diagnosis very difficult and may cause delay (22). Taga et al. (23) reported that nausea, vomiting, and photo and phonophobia were MLF that are observed in approximately $46 \%$ of patients with $\mathrm{CH}$, wherein these features were related to female gender and early onset was associated with a longer duration of pain, as well as more frequent sweating and ptosis. Our study observed MLF in 28.1\% of patients. Our results showed that pain duration was longer in these patients, compatible with the literature; however, this data was not statistically significant. When other sociodemographic and clinical characteristics were compared, statistically significant results were also not observed. Studies with larger cohorts should be conducted for a solid conclusion.

Triptans and oxygen inhalation have an important role in the treatment of $\mathrm{CH}$ attacks. Non-steroidal anti-inflammatory drugs (NSAIDs) are known to have no place in this condition. Corticosteroids, such as prednisolone, also have a place in severe attacks. Our study revealed that triptans alone or in combination with prednisolone were used in $71.8 \%$ of patients during the attack period, and all of them were treated with oxygen inhalation at least once. Recently, other triptans have become more common in Turkey due to insufficient sumatriptan and zolmitriptan. The effects of NSAID drugs are limited; however, 9.3\% of our patients used this during their attacks. Verapamil and lithium are particularly recommended in the prophylactic treatment of $\mathrm{CH}$. Our study observed that verapamil was used in $56.2 \%$ of patients. Although $18.7 \%$ of our patients were on valproic acid, alone or in combination with verapamil, evidence is still insufficient about its effectiveness $(2,24,25)$.

\section{Study Limitations}

This study has several limitations, including the small number of patients, lack of documentation of patient treatment responses, and quality of life.

\section{Conclusion}

This study reviewed the clinical findings of $\mathrm{CH}$. The delay in diagnosis due to accompanying MLF shows the importance of increasing awareness in $\mathrm{CH}$ definition. Future studies with more patients that are planned to be multicenter will provide us with more detailed data on the pathophysiology, clinical findings, and prognosis of $\mathrm{CH}$.

\section{Ethics}

Ethics Committee Approval: Approval was obtained from University of Health Sciences Turkey, Istanbul Bakirkoy Dr. Sadi Konuk Training and Research Hospital in 01.02.2021 with the number 2021/03.

Informed Consent: Retrospective study.

Peer-review: Externally peer-reviewed.

\section{Authorship Contributions}

Concept: F.E., G.G., Design: F.E., G.G., Data Collection or Processing: F.E., G.G., Analysis or Interpretation: F.E., G.G., Literature Search: F.E., G.G.

Conflict of Interest: No conflict of interest was declared by the authors.

Financial Disclosure: The authors declared that this study received no financial support.

\section{References}

1. Fischera M, Marziniak M, Gralow I, Evers S. The incidence and prevalence of cluster headache: a meta-analysis of population-based studies. Cephalalgia 2008;28:614-618.

2. Ljubisavljevic S, Zidverc Trajkovic J. Cluster headache: pathophysiology, diagnosis and treatment. J Neurol 2019;266:1059-1066.

3. Zidverc-Trajkovic J, Markovic K, Radojicic A, Podgorac A, Sternic N. Cluster headache: Is age of onset important for clinical presentation? Cephalalgia 2014;34:664-670.

4. Headache Classification Committee of the International Headache Society (IHS). The International Classification of Headache Disorders, 3rd edition (beta version). Cephalalgia 2013;33:629-808.

5. Hoffmann J, May A. Diagnosis, pathophysiology, and management of cluster headache. Lancet Neurol 2018;17:75-83.

6. Goadsby PJ, Edvinsson L, Ekman R. Release of vasoactive peptides in the extracerebral circulation of humans and the cat during activation of the trigeminovascular system. Ann Neurol 1988;23:193-196. 
7. Akerman S, Goadsby PJ. Neuronal PAC1 receptors mediate delayed activation and sensitization of trigeminocervical neurons: relevance to migraine. Sci Transl Med 2015;7:308ra157.

8. Storer RJ, Akerman S, Goadsby PJ. Calcitonin gene-related peptide (CGRP) modulates nociceptive trigeminovascular transmission in the cat. $\mathrm{Br} \mathrm{J}$ Pharmacol 2004;142:1171-1181.

9. May A, Bahra A, Büchel C, Frackowiak RS, Goadsby PJ. Hypothalamic activation in cluster headache attacks. Lancet 1998;352:275-278.

10. Tuka B, Szabó N, Tóth E, et al. Release of PACAP-38 in episodic cluster headache patients - an exploratory study. J Headache Pain 2016;17:69.

11. Moon HS, Park JW, Lee KS, et al. Clinical features of cluster headache patients in Korea. J Korean Med Sci 2017;32:502-506.

12. Manzoni GC, Camarda C, Genovese A, et al. Cluster headache in relation to different age groups. Neurol Sci 2019;40(Suppl 1):9-13.

13. Rozen TD, Fishman RS. Female cluster headache in the United States of America: what are the gender differences? Results from the United States Cluster Headache Survey. J Neurol Sci 2012;317:17-28.

14. Chung PW, Lee MJ, Park JW, et al. Differences of cluster headache on the basis of sex in the Korean cluster headache registry. Headache 2019;59:17221730.

15. Rozen TD, Fishman RS. Cluster headache in the United States of America: demographics, clinical characteristics, triggers, suicidality, and personal burden. Headache 2012;52:99-113.

16. Rossi P, Allena M, Tassorelli C, et al. Illicit drug use in cluster headache patients and in the general population: a comparative cross-sectional survey. Cephalalgia 2012;32:1031-1040.
17. Lambru G, Matharu M. Traumatic head injury in cluster headache: cause or effect? Curr Pain Headache Rep 2012;16:162-169.

18. Joshi S, Rizzoli P, Loder E. The comorbidity burden of patients with cluster headache: a population-based study. J Headache Pain 2017;18:76.

19. Waung MW, Taylor A, Qualmann KJ, Burish MJ. Family history of cluster headache: a systematic review. JAMA Neurol 2020;77:887-896.

20. Russell MB, Andersson PG. Clinical intra- and interfamilial variability of cluster headache. Eur J Neurol 1995;1:253-257.

21. Taga A, Russo M, Manzoni GC, Torelli P. Familial cluster headache in an Italian case series. Neurol Sci 2015;36(Suppl 1):141-143.

22. Uluduz D, Ayta S, Özge A, Yalin OÖ; Turkish Headache Database Study Group, Temel GÖ, Taşdelen B. Cranial autonomic features in migraine and migrainous features in cluster Headache. Noro Psikiyatr Ars 2016;55:220224.

23. Taga A, Russo M, Manzoni GC, Torelli P. Cluster headache with accompanying migraine-like features: a possible clinical phenotype. Headache 2017;57:290-297.

24. Robbins MS, Starling AJ, Pringsheim TM, Becker WJ, Schwedt TJ Treatment of cluster headache: the american headache society evidencebased guidelines. Headache 2016;56:1093-1106.

25. Guo XN, Lu JJ, Ni JQ, et al. The role of oxygen in cluster headache. Med Gas Res 2019;9:229-231. 